\title{
5 \\ Agency and selfhood among young Palauan returnees
}

\author{
Rachana Agarwal
}

\section{Abstract}

This chapter examines the phenomenon of reverse mobility to the Micronesian island of Palau through the perspective of three relatively young Palauan females. The transnational networks that facilitate travel along with key aspects of Palauan social organisation that influence and shape returnees' experiences are described. Importantly, the category of youth is analysed as a culturally constructed subaltern designation within Palauan society, such that those believed to belong to this substratum are structurally subordinated to Palauan elders. In light of the age-related social dichotomy between the younger and the older populations, efforts to exercise agency and assert autonomy by young Palauans transitioning back to life on their home island emerges as a crucial theme. Through extended narratives, I demonstrate how young returnees strive to carve out their own social positions by continuously negotiating their roles in Palauan society. Doing so constitutes an agentive act that is intimately linked to the construction of selfhood. The presented cases are theorised using conceptual tools proposed by Holland et al. Together, they provide insight into the experience of return migration from an age-based gendered lens. 


\section{Introduction}

Mobility is a familiar theme in Palauan myths and legends. The earliest written record of foreign travel dates from the 18th century and chronicles the journey of a young Palauan of about 20 years of age. This historically significant event dates as far back as 1783 when Lee Boo, the son of a Palauan chief, Ibedul, accompanied Captain Henry Wilson all the way to England (Keate 2002 [1788]; Peacock 1987). Unfortunately, however, he succumbed to smallpox during his stay there and, consequently, his dream to return to his homeland remained unfulfilled. He never set foot in Palau again. Despite its tragic end, it is almost as if Lee Boo's seminal voyage set in motion the modern trend of Palauan youth ${ }^{1}$ travelling to distant shores to acquire foreign knowledge and skills. Unlike their predecessor, however, today's youth frequently move back and forth between their homeland and other countries, returning either for short vacations or to finally drop anchor in Palau.

Nowadays, young Palauans chart multiple trajectories to numerous foreign destinations, ranging from the east coast of the US mainland to Taiwan and New Zealand. Their geographic spread and frequency of travel is in keeping with recent scholarship on youth culture and globalisation and exemplifies the observation that contemporary youth traverse local and international boundaries with increasing speed and effortlessness (Dolby and Rizvi 2008; Wulff 1995). Hezel (2001) has noted increasing migration trends in Micronesia (2001: 144-145), and Nero and Rehuher (1993) comment on gender-based migration patterns, pointing out the slightly higher number of Palauan females pursuing education abroad (1993: 251). While educational endeavours, employment, enlistment in the American military and living with relatives overseas are the key reasons that pull youth away from Palau, their motives to return are more diverse: to care for ageing kin members, meet familial and customary obligations (siukang), retain land ownership, pay off student loans, for holidays, because of financial and circumstantial reasons, to experience a sense of belonging lacking elsewhere or to finally realise their original intent to resettle in their homeland.

1 I use the terms, 'youth' and 'young Palauans/returnees' interchangeably for convenience and to connote how such persons are perceived by Palauan elders. However, these relatively young persons, most of whom are in their 20 s or early 30 s, may not all perceive themselves as 'youth'. They are nevertheless defined as such in the Palauan sociocultural context where adulthood is signalled at 35 or 40 years of age. 
However, homecoming may not be a smooth and seamless process for all youth. Aside from individual particularities, underlying sociocultural factors, such as the cultural construction and social position of youth within multiple scales of hierarchy, may complicate the transitional life back home. In normative terms, youth maintain a markedly subordinate position to those categorised as mature adults and elders. Importantly, however, the social categories of young and elderly Palauans, while distinct, are not static or immutable. Many Palauan elders today may have sojourned overseas in their youth and would likely have been exposed to alternative lifestyles. In fact, they may continue to travel abroad for conferences, workshops, medical treatments or to visit their children and relatives residing outside Palau. Nevertheless, upon return, they often become gradually steeped and invested in Palauan customs and politics, and thereby come to embody an intensely hierarchical social system. Palauan elders may be keen to exert local authority and maintain the status quo as they benefit from it. Their adherence to Palauan social norms effectively continues to privilege elders and may be perceived as oppressive by some youth.

The culture of deference towards elders (omengull), a linchpin of Palauan society, relegates young returnees to uncomfortable and structurally disadvantageous positions. This includes cases when returnees are deemed subaltern despite attaining impressive academic qualifications elsewhere or being single parents well into their 30 s and wishing to raise their children in their homeland. Readjusting to life in Palau involves inhabiting or reinhabiting a socially designated position determined largely on the basis of clan ranking order and kinship, especially one's maternal ancestry (Barnett 1949; Smith 1983; Parmentier 1987). Young people are usually considered extensions of their families and not independent individuals in their own right. Being constantly perceived as such upon return may result in a conflicted identity or a subtle shift in one's sense of self as the young person struggles to confine him or herself to a predetermined and externally imposed social role. Therefore, the reception of young returnees in Palauan society emerges as a cogent determinant of their lived experiences at home and has an enduring influence on self-construction. After an initial period of adjustment, some returnees find the sense of belonging, rootedness and contentment they may have been seeking. Others report feelings of discontent, disillusionment, frustration and ambivalence resulting from factors such as how youth are generally 
perceived, their unmet expectations of an imagined homeland, local politics, nepotism, and the difficulty of readjustment to the work culture as well as the social environment in Palau.

I draw on data gathered from two preliminary fieldtrips to Palau in 2006 and 2007, and extended fieldwork from 2008 to 2009, to present three individual narratives of young Palauan female returnees. All three, Hannah, Diana and Dilumang, ${ }^{2}$ were highly educated, unmarried young women at the time. Diana was in Palau for an extended visit- one of many such circular transnational movements. Hannah and Dilumang, on the other hand, had chosen to permanently resettle in Palau. Gendered experiences of mobilities of return are especially significant in light of the matrilineal emphasis in Palauan social organisation. All three females, two of whom were then in their mid-20s and one in her early 30s, came from privileged backgrounds, in the sense that their respective families could comfortably provide for their needs and education, hire domestic help and make arrangements for foreign travel and even employment for their daughters. Two of the families were quite prominent socially and enjoy elevated rank in the clan system. In sum, they represent the elite of Palauan society.

As this chapter demonstrates, despite their socially structured subordination, young returnees do not passively accept the position that is expected of them. Instead, they actively negotiate their roles in society and strive to assert autonomy and individuality while at the same time integrating into the community hierarchy. When examining individual narratives, I conceptualise agency and selfhood as closely related analytic constructs, such that the self may be continually fashioned, contested, validated and transformed through actions of the individual and through interactions with social relations, such as kin and community members. I draw on the theory of identity proposed by Holland et al., defined as emotionally imbued 'self-understandings' ${ }^{3}$ (1998: 3), and their concepts of positional identities, agency as improvisation and the balancing of culturalist and constructivist principles in the construction of selfhood, all of which are explicated in some detail later. Within this framework,

2 All names are pseudonyms and I have deliberately concealed and changed some revealing details about my Palauan interlocutors to maintain anonymity.

3 Since selfhood is implicated in the very definition of identity, Holland et al. sometimes use 'identity' and 'self' interchangeably. I mostly use selfhood instead of identity, even though both are assigned the same conceptual and analytic meaning. 
the central goal of this chapter is to examine the constellation of sociocultural, political, economic and transnational structural forces that enable, shape and restrict young Palauans' choices, and identify elements of youth agency as they navigate life in Palau.

Perhaps reflecting the socially inferior position of youth in Palauan society, youth perspectives are virtually absent in the ethnographic literature on Palau (Agarwal 2013). By contrast, my intent here is to emphasise the individual voices of my young interlocutors. Hence, I present extended narratives and excerpts from recorded conversations to highlight their unique, emotionally resonant 'self-understandings'. In doing so, I hope to highlight the act of narrating one's story as an important agentive process. To background this agency, I begin with a description of various transnational and local structures involved, followed by a discussion of some patterns of recent reverse mobilities in Palau.

\section{Structures of transnational relations and social hierarchies}

A confluence of transnational and local sociocultural factors set the parameters for youth mobility. As a nation, Palau maintains different political-economic alliances, and such international ties not only shape, but actually 'create' the possibility of transnational migration. Two of these relations, one with Japan and the other with the US, stem from Palau's complex and extensively documented colonial history (Gale 1979; Heine 1974; Hughes and Lingenfelter 1974; Leibowitz 1996; McHenry 1975; Nevin 1977; Kiste 1993).

Japan colonised Palau between the two world wars until its eventual defeat at the end of the Second World War led to the advent of the American administration in Micronesia. Since decolonisation in the mid-1940s, Japan has resumed cordial political-economic ties with Palau, which is manifested through, among other measures, the provision of scholarships and grants for educational pursuits. This allows young Palauans to travel between the two countries with relative ease. After the Second World War, various Micronesian states, including Palau, were declared United Nations Trust Territories to be administered by the US. Charged with the task of 'developing' Micronesia, the US cultivated a persistent economic dependence on the islands that was formalised through the 
Compact of Free Association, which, for Palau, came into effect with political independence in 1994. Under this agreement, Palau has received staggering amounts of financial assistance from the US, with a trust fund valued at $\$ 147$ million set up since the last comprehensive review of the Compact in 2010 (US Department of State website). This strategic relation continues to enable Palauans to travel, study and work freely in the US. Palauans also enlist in the American military and may attain dual citizenship. Academic pursuit in the US is one of the main reasons for youth mobility, however, and numerous sources of financial support make this avenue a realistic and affordable one. In addition, youth also travel frequently to the Philippines, Taiwan, New Zealand, Fiji and other nations to study.

Complementing such opportunities, the Palauan government has established the Palau National Scholarship Board (PNSB), a state apparatus that provides educational loans, scholarships and grants to Palauan citizens. Importantly, PNSB conditions stipulate the return of citizens to serve in their homeland for specified lengths of time. Thus, youth may be obliged to return to pay off student loans and may find it necessary to secure employment in Palau for many years to do so.

While financial incentives from foreign entities and Palau's own national resources facilitate the transnational movement of youth, social organisation within Palau critically impacts young returnees. Palauan social structure may be divided into two broad categories, including klou el chad, elders and mature adults, on the one hand, and kekerei el chad, children and young people, on the other (Parmentier 1987). This division creates a fundamental hierarchy such that the young must defer to elders and give them obeisance (omengull). Consequently, youth are expected to constantly police themselves and be mindful of their behaviour, speech and actions, especially when in the company of elders. Indeed, on an island such as Palau, where there is intense social and spatial proximity because of its relatively small population and limited geographic size, heightened surveillance and lack of anonymity impacts everyone regardless of age.

In Palau, a person's agency and identity is heavily defined by her or his socially designated position and the responsibilities and rights that such positioning entails. The concept of positional identity defined by Holland et al. (1998) is particularly applicable to the Palauan context as it operates on the premise that a person's identity is founded within existing social hierarchies. They maintain that, 'positional identities are about 
acts that constitute relations of hierarchy, distance, or perhaps affiliation' (Holland et al. 1998: 128). Youth's positional identities are established by a confluence of factors: age, primogeniture, genealogy, rank of clan, village, state and gender being some of the most important determinants. All Palauans occupy specific social positions, of course, but in the case of youth, their age subjugates them to Palauan elders. The culture of deference imposes a tangible yoke on youth and limits their actions both publicly and privately. It permeates their relationships with elders and may sometimes create a socially stifling or oppressive environment.

Operating within such social hierarchies involves the dynamic interplay of individual desires and societal expectations. This is encapsulated in two approaches offered by Holland et al. - the culturalist approach that emphasises the influence of social norms in regulating behaviour, and the constructivist approach that underscores agentive improvisation by individuals. From the culturalist perspective, behaviour is guided by the expectation of social conformity such that an individual 'seeks to conduct herself so as to do right by a preconstituted, culturally given, moral world' (1998: 13). However, actors are bound to encounter situations 'that do not fit the rules' (Holland et al. 1998: 13), in which case they will be compelled to improvise and act in ways that may not be foreseen or dictated by cultural convention. Hence, according to Holland et al., the culturalist approach does not account for improvisation whereas, 'constructivists think of improvisation as an expected outcome when people are simultaneously engaged with or pushed by contradictory discourses' (1998: 17). Applied to the Palauan context, the culturalist paradigm may grant youth 'greater or lesser access to spaces, activities, genres, and through those genres, authoritative voices, or any voice at all' (Holland et al. 1998: 127-128). In the Spivakian sense, strict adherence to culturalist principles may not allow youth the 'space' to voice their thoughts, feelings and concerns or exercise agency when immersed in Palauan society (Spivak 1988).

One of my interlocutors, Diana, who I introduce in more detail below, once mentioned a Palauan phrase that is sometimes used to derisively remind a woman of her social position by likening the person to her mother. This remark, 'Ke kora di ua delam' ('You are just like your mother'), is considered an insult and can be extremely provocative. This is especially the case given the matrilineal context, where one's maternal 
ancestry ${ }^{4}$ commands reverence and must not be casually discussed in public. Diana translated and explained the phrase in the following words: 'You're just like your mother, because usually peoples' opinions of you are based on your family; not on what you do, like as an individual, but who your family [is]'. This instant identification of a female with her mother, and consequently her maternal lineage, positions a person along lines of descent within the larger social matrix. Youth are expected to comprehend and internalise their social position so as to appropriately behave and interact with other Palauans, especially elders. A Palauan's social position therefore informs her (or his) sense of self in fundamental ways.

Another crucial social determinant relating to lineage is the identification of a child with the maternal or paternal matrilineage. Although descent may be traced bilaterally (Barnett 1949), the emphasis on matriliny dictates that a 'child of the woman' (ochell) is entitled to primary rights whereas a 'child of the man' (ulechell) has secondary rights (Smith 1983: 42). A youth may be able to exercise greater agency in his or her maternal home(s) in comparison to the paternal one(s). Beyond the hierarchies of age and genealogy, each clan in every village, every village in each state, and all 16 Palauan states are also ranked (Vidich 1949; Parmentier 1987). Therefore, youth are expected to be cognisant not only of their age and maternal and paternal affiliations, but also of the social order of their clan, village and state when calibrating their social status in relation to other community members. All of these sociocultural factors constitute the structural forces that influence the everyday lives of Palauan youth.

Using the analytic tools developed by Holland et al. (1998), I present three cases of female returnees, describing their adaptive processes in Palauan society. These are not intended to be representative of young returnees at large. Instead, their voices are those of a gendered and educationally accomplished segment of Palauan society that has the resources to facilitate transnational mobility. Furthermore, the narratives I present capture only partial fragments of their lives. The primary aim is to spotlight how they perceive themselves and their roles in Palauan society.

4 Various female kin, such as aunts and grandmothers, may take on caregiving roles and occupy the same position of maternal authority. 


\section{Trends in return mobilities}

In recent history, Micronesian migration trends have soared since the 1960s, primarily because of the policy changes introduced by the US Kennedy administration (Nero and Rehuher 1993). Following an initial period of 'benign neglect' (Kiste 1993: 70), the eventual American investment in the 'development' of Micronesia and Micronesians generated considerable opportunities for islanders to not only travel to the US for educational pursuits, but also to return to their island homes to find employment, particularly in various administrative capacities (Nero and Rehuher 1993). Palauans benefited enormously in this regard, and a large proportion returned to Palau in the 1980s, a period in which a sense of national identity was heightening. Many were employed in the government as well as the growing private and service sectors in the emerging Palauan nation. One of my older male interlocutors reported that he had chosen to return to Palau in his youth many years ago because he felt like a 'nobody' in Hawai ' $\mathrm{i}$, while he had the comfort of a recognised social position in Palau. Likewise, many people in the contemporary population of elderly Palauans have previously lived abroad, especially in the US, for lengthy periods before finally resettling in Palau. Numerous political figures in the elected government, highly respected authorities and titleholders in the chiefly system, teachers, medical professionals, educational administrators, entrepreneurs and local social scientists, among others, have had prior experience in the American military or substantial exposure to overseas educational systems. Such persons, who may be recognised locally as successful returnees, have, in effect, created a now well-trodden path for all kinds of foreign pursuits followed by eventual return to the homeland. They have set forth a pattern of 'chain migration' and have provided a 'living demonstration to young adults in the community' of the possibilities of mobility (Gmelch 1980: 153; LeeCunin 2005: 125.) In conversations, I observed that many Palauan youth do, in fact, perceive such socially established figures as role models and attribute their success to their foreign-earned credentials.

Over the years, Palauans have established extensive networks of social relations stretching across and beyond the Pacific Ocean to facilitate international mobilities. Asang employs the Palauan linguistic term klaingeseu to refer to the process of mutual assistance and social support for foreign travel, and describes it as 'a tapestry of helping hands' (2000: 371). Youth mobility for educational pursuits is heavily encouraged by 
most Palauans. Parents consider their foreign-educated children a form of social capital and their success overseas is equated with greater prestige for the family. This trend is in keeping with traditional practices of sending youth outside the home or village to gain foreign skills and knowledge and use them for the benefit of the kin group upon return. Lee Boo, introduced in the opening paragraph, embarked on his voyage with Captain Henry Wilson with exactly this intent.

Unlike the initial wave of migrants who returned and secured employment in newly opened administrative positions in the developing government, job opportunities may not be as easily available for contemporary returnees. Therefore, some believe that Palauans who have found work stability outside Palau would be better off not resettling in their homeland. Instead, they could serve their families and nation by living abroad and sending remittances back home. Many, however, especially parents, want their children to eventually re-establish their base in Palau, where they can find a Palauan partner, start a family and live close to their natal kin. Familial ties often constitute a strong 'pull factor' (Gmelch 1980) for youth to re-establish themselves in Palau. Re-entry may be voluntary and intentional, motivated by long-term resettlement, it may involve several transitory visits and vacations while living abroad, or it may be reluctant or forced because of circumstantial necessity.

The manner in which the Palauan community may receive returnees tends to change with the passage of time. Initially, returnees may be welcomed but also 'othered' to some degree, and may be perceived as outsiders or newcomers on the social scene (Conway et al. 2005: 15). Sometimes this may be manifested linguistically, by addressing a person by her Englishderived name, such as Diana or Hannah, instead of the more socially intimate Palauan name, such as Dilumang. ${ }^{5}$ The general view held by Palauan resident elders of returnees is that they are young, fresh and confident with new ideas, and need to be reintegrated into the community by relearning social norms and acceptable codes of conduct. For instance, dressing conservatively and not provocatively, especially for women,

5 With a few exceptions, most Palauans I met had two first names: one foreign, English-sounding name and one Palauan name. I did meet some Palauans who had only a Palauan name, but none who had only a name of foreign origin. The foreign name is mostly used in public or formal settings, such as in school, at work and so on, whereas, the Palauan name is usually known to kin members and very close friends. It is usually derived from the individual's maternal or paternal genealogy. Hence, the Palauan name is imbued with a familial, intimate, personal meaning and symbolises a person's social link with the matrilineage. 
displaying humility and deference to elders, and being proficient in Palauan are all desirable qualities for successful reintegration into Palauan society. Some returnees cross this threshold of cultural appropriateness more easily than others and in doing so may experience more harmonious transitions.

From a cross-cultural perspective, gender has emerged as an important analytic category in the literature on return migration (Conway et al. 2005; Gmelch 1980; Koning 2005; Lee-Cunin 2005; Nero and Rehuher 1993; Pérez 2005; Potter and Conway 2005), and its significance is conspicuous in the Palauan case as well. For instance, findings by Caribbean scholars reveal that female returnees may experience isolation, disenchantment and frustration because of their confinement to the domestic sphere (Pérez 2005: 192-193), and may report 'the loss of the gendered gains made in metropolitan societies' (Potter and Conway 2005: 285). In the Indonesian context, Koning (2005) foregrounds the 'clash of values' (Koning 2005: 166) that Javanese female migrant labourers experience when attempting to reconcile divergent rural and urban values regarding motherhood and marriage in their lives. Nero and Rehuher (1993: 251) discuss the demands of customary obligations and the considerable social responsibilities saddled on women once they return to Palau. The three cases studies that follow complement such scholarship and offer some insight into the individual struggles of young female Palauan returnees.

\section{Hannah: 'It was my choice'}

Hannah was a 27-year-old computer studies teacher in a school in Palau, who had strong ties with her paternal family. She had lost her biological mother in her early teenage years and had subsequently been raised by her father and her paternal grandparents. In fact, she had come to think of her paternal grandmother as her mother and that was how she addressed her. Having left Palau in 1998 to pursue computer science on the west coast of the US mainland, she had returned to Palau for a holiday in 2001, and was scheduled to leave for the US right after the September 11 incident. On this occasion, her grandmother expressed deep concern for her safety and advised her to stay in Palau, get married and find employment instead of returning to the US. However, Hannah was determined to resume her academic training and stood her ground by deciding to return to the US. She reassured her family that if the situation in the US worsened, she would call home every day to remain in constant 
touch with them. She was emphatic in her assertions to her family and confidently told me: 'It was my choice'. She explicitly framed her decision to continue her studies in the US as a manifestation of her agency. In this instance, her agency emerged in opposition to the wishes of her family as she chose to adopt the constructivist paradigm over the culturalist one that her family preferred. Similarly, she decided of her own accord to return to Palau in 2004. In her words:

After I graduated [from] college I decided that I had to move back home. And just spend as much time as I had with my grandmother before she passed away because [brief pause] I don't want to have to feel the same feelings that a lot of Palauans go through when you're in the States and a loved one passes away and you just come here for the funeral. I wanted to spend some time with her before she passed away. So, yeah, it was really my choice. I actually just graduated and a week later I flew out. I didn't really care about my stuff. I just gave them up for free because I just wanted to just come back home.

I asked if her family had been surprised with her decision and she affirmed that they had. She moved in with her grandmother and shouldered all her responsibility by taking care of the expenses, and she even assumed the duties of the Filipina domestic helper whom her sister had hired to attend to her grandmother. Hannah appeared to be very content with her decision and did not seem to think of it as a sacrifice at all. Over time, her desire to play a particular social role and her family's expectations of her had become aligned. She wholeheartedly embraced the culturalist paradigm and recognised her choice to do so as a self-agentive act.

It is possible that Hannah's decision to eventually return to Palau was motivated by strong pull factors, such as her affection for her grandmother and the internalised cultural obligation of intergenerational reciprocity, according to which the caregiving of ageing kin members is expected from offspring in return for the care received by them in formative years. However, Hannah emphasised her conviction that her movements between Palau and the US were a direct product of her own agency and not a consequence of succumbing to social pressure. She identified the prioritisation of her social obligations in Palau as a marker of her agency, just as much as her decision to continue studying computer science in the US. 


\section{Dilumang: 'What you think of yourself is not how people see you'}

I first met Dilumang at an educational institution in Koror where she was an adjunct faculty member. When I expressed my desire to contact her later she handed me her business card imprinted with the emblem of a distinguished American university, establishing her as a $\mathrm{PhD}$ candidate in a social science department. Our first substantive conversation took place in September 2008, when we met for lunch at a local restaurant. We talked about a Palauan historic preservation symposium that we had both attended. Dilumang remarked on the presence of students at the symposium, which she noted was setting a precedent of sorts since conventionally only adults, mostly Palauan elders, participated in such events. It was gradually becoming clear to me that she was fairly critical of the structural subordination of youth in Palau. She commented that with regard to her own academic accomplishments she refrained from openly announcing her doctoral candidacy since she had returned to Palau, as elders would be quick to put her in her place. Although she was in her early 30s, her experiences had led her to believe that she was still categorised as a young person in Palauan society. She complained that even though she worked multiple jobs and had a steady income, her relatives treated her as a youth and would not let her contribute financially in siukang (Palauan customs). She considered this an upsetting affront because she thought of herself as an economically independent adult, a single parent and someone who was striking out on her own without exploiting the clout her family had in Palauan society. Moreover, she was eager to participate in customs to better integrate into Palauan society since she had lived abroad for many years. She surmised that, had she been married, her relatives would have expected her to contribute financially. But because she stood on her own, her relatives believed the family should extend support to her instead of the other way around.

Our mutual interest in the social sciences eventually steered our conversation to our respective scholarly pursuits. It seemed to me that her academic training had enhanced and mobilised her political consciousness about Palau's standing in the world as an independent nation-state, and provided her with a vocabulary to articulate her stance on issues pertaining to cultural revitalisation, especially in the face of Palau's ongoing relations with powerful foreign countries. We shared a postcolonial perspective and she remarked that subaltern theory, 
especially the work of the Indian scholar, Gayatri Spivak, resonated with her. I found it fascinating that although she had devoted herself intellectually to the promotion of Palauan cultural nationalism while a student in the US, her lived experience in Palau was fraught with ambivalence and frustration. Her narratives revealed a profoundly knotty relationship with her kin members and Palauan society at large, complicating her sense of self and belonging in the midst of people who were constantly putting her at arm's length in terms of her involvement in the community.

Upon request, Dilumang offered a detailed account of her coming of age in a fractured family. The first two decades of her life were characterised by familial rupture, discord and locational instability. Her parents had a difficult marriage, which was followed by divorce and a complete severing of ties between the maternal and paternal sides of her family. Living periodically with either her mother or father after their divorce, or a relative, she had shuttled back and forth between the American Midwest, Hawai $i$, Guam and Palau. Unavoidably, she slipped in and out of many schools in these places, sometimes every couple of years, depending on which parent she was living with at the time. Legal custody had been granted to only one of the parents and consequently she was expected to completely dissociate herself from the other parent. Eventually, she was able to exercise her will and live with the parent who most keenly attended to her needs and interests. That she managed to keep an impressive academic record despite domestic strife, frequent transitions and changing educational environments, all factors beyond her control, demonstrated her incredible resilience. I wondered aloud if people in Palau recognised her accomplishment of having defended her dissertation proposal. She responded:

No. So that was a very personal thing for me ... establishing that faith in myself ... It had nothing to do with what I felt people would perceive of me ... the fact that I'm ABD [all but dissertation] now, nobody really understands what that means here. And it's not important. But the fact that I understand what it means and what it's meant for me, gives me the confidence to be here and ah, actually function day to day, as myself. You know, I didn't feel like I had that, uh, stability before. Yeah, I feel like I am grown up now. [Chuckles.] You know, like I can stand on my own two feet and not constantly have to say that 'Oh yeah, I am my dad's daughter and my mum's daughter' for that to give me some kind of grounding ... 
So a lot of people are actually very intrigued by the fact that I chose this moment to return. And ... I can't explain it to them because it's a very personal thing that they probably can't understand, you know.

Dilumang explained that her uncles constantly questioned her determination to complete her doctoral studies. 'Just forget it' and 'you don't need it', were usually the sort of comments she received with regard to her degree. Her relatives wondered what she would 'do' with a $\mathrm{PhD}$ when she resettled in Palau. This was why her brother, who resided in the US, had expressed misgivings about her decision to return, afraid she may lose sight of her educational goals. Dilumang asserted, 'I need it [the $\mathrm{PhD}$ ] for myself. It's something that I need to do for me. I've started it and I want to finish it'. Her doctorate was imbued with a deeply personal, symbolic meaning and was a source of self-validation. Education was a way of exerting agency and getting a sense of control in her otherwise chaotic life. It was an opportunity for her to reconstruct herself, or improvise, to use Holland et al.'s term, outside the constraining parameters of the Palauan social environment. Every milestone in her academic trajectory was a source of strength and self-confidence that emboldened her to face the emotional and psychological demands of life in Palau. Consider the following dialogue in which she describes her efforts to reposition herself in Palauan society:

Dilumang: ... it was always uncomfortable for me to return home, and walk around on this island and not even know anybody. And I would be walking by my relatives and they'd be like, 'Oh, are you so-and-so's daughter.' And I'd be like 'Yes, I'm sorry I don't know who you are. I should know, you know.' I was always constantly apologising for not knowing something about something or somebody. And, so I wanted to be able to have some grounding before I returned home. And have something to contribute. And once I defended my proposal I felt like I had the tools, um, to come back and be able to learn without being afraid to learn ... That's why I felt comfortable coming home. Even though everybody that I knew [relatives in the US] discouraged me ... And then everyone here [in Palau] kept saying, 'It's about time [you returned to Palau]. But now that you're here what are you gonna do?' You know, so they've all been sort of waiting and anticipating my next move. And watching me. [pauses] And everyone always says, 'Oh you're so stubborn', you know. And it's because I don't wanna, ah, manoeuvre in society because I am related to so-and-so. I want it to be based on my merit, my work, my brain ... me. And so, me not getting assistance from some of my family, ah, has been like me turning my back. They think I'm stubborn and [pauses] 
Rachana: Did they offer assistance?

Dilumang: Oh yeah.

Rachana: You declined.

Dilumang: Graciously. [Laughs] Graciously.

She continued:

Dilumang: There were all these different offers. But I really just didn't wanna [pauses briefly] get a job like that. So I've been struggling to find work on my own ... It's been very difficult to sell myself here because people know who I am automatically. And so I think they are suspicious about why I am not affiliated with my family and why I would wanna work in places where I have applied ... But then some of, um, I've been participating in different things and so some people are talking to me and realising, you know, that I am actually interested in other things. And so, I've been getting other kinds of offers lately, which is kind of nice. Which is how I found out about this particular job opening ... And then my Dad asked me to help him work in [his home state]. And that is no way anywhere near what I wanna do.

Dilumang's polite refusal to accept financial assistance from her family or to capitalise on their social influence to secure a job illustrates the claim by Holland et al. that 'identities are hard-won standpoints that, however dependent upon social support and however vulnerable to change, make at least a modicum of self-direction possible' (1998: 4.). Her insistence on defining herself as a separate individual with her own mind and ability to make her own decisions, despite being a part of her natal family, demonstrates her agency. The associations that Palauans 'automatically' made between her and her family, despite her efforts to establish herself independently, explain her comment: 'What you think of yourself is not how people see you'. She yearned to be recognised as an accomplished scholar and an independently contributing member of Palauan society, but was usually perceived with paternalism as a child of her family. Although aware of it, she was not deterred by the unceasing scrutiny to which she was subjected. Nor was she dissuaded by the social pressures her well-wishers feared she would encounter in Palau. She emphasised: 'I want to create a niche on my own', and she persevered in doing so upon returning to Palau. 


\section{Diana: 'I can't say l'm a hundred per cent Palauan anymore because ... living abroad has changed me'}

Diana had one foot in Palau and the other in Hawai' $i$; in the former she was her parents' daughter and the latter a graduate student. Her transnational lifestyle had made her acutely sensitive to the distinct behavioural codes and expectations she observed in the two places as she constantly shifted cultural gears to readjust to each. She lived in Hawai' $i$ for long stretches of time, which were periodically interrupted by return trips to Palau, especially during the holidays. Although this to-and-fro movement across the Pacific occurred with ritualistic regularity, uprooting from one place and transplanting to the other had not become easier over the years. Returning to Palau always signalled a careful change in her presentation of self, especially when in the company of Palauan elders, which she explained in a style characteristic of Goffman (1956):

Diana: You have to act, act, um, differently [in Palau]. Slower in your movement, the way you talk. Make sure you talk at the right time. Um, don't come out too strong. Don't speak your mind. Respect what they say even if you think it's wrong. Don't be too opinionated, you know ... Even when you're walking, there's a way ... [to] hold yourself. I mean, if they're [Palauan elders] around you and you're walking make sure you always bow. You cannot walk straight up.

In these vivid details, Diana accentuates the performance of deference towards elders and how it is embodied in practice. A change in behaviour with every transnational move is not merely a superficial change in performance at that moment but requires a subtle shift in her sense of self as she plays culturally distinct roles. Diana believed that living abroad for extended periods of time had made her 'a diasporic person', and that such an experience 'sets you in a different space'. Hence, she claimed, 'I can't say I'm a hundred per cent Palauan anymore because ... living abroad has changed me'. She reflected that one of the outcomes of such a transformation was that when in Palau, she felt most at ease with people who had, like her, been exposed to the world outside for substantial periods. On one occasion, we were discussing the subject of social acceptance in Palau and how comfortable both she and I felt when spending time with her friends. However, she did not think this was as simple a matter as I made it out to be. She clarified: 
Diana: People you hang out with are not typical Palauans. Not, oh no, let me rephrase that. That's, that's problematic. Not that they're not typical Palauans, but they've been outside so they're more open-minded to, like, me. I'm comfortable because I can express myself ... and they're okay with it, you know, because they're the same way. Or they know what it's like out there, knowing how you've changed. Like I cannot speak to like just regular Palauans that way. They'll look at me weird, or like 'Wow! This is a new [name of speaker]!' You know! So when I speak to like mechas [elderly Palauan women] and you know my aunties then I have to try my best to speak Palauan because they respect you more ... Maybe it's just me thinking that if I talk Palauan more I'll be more accepted. I don't know. I talk Palauan and be more respectful to them. It's [a] different me.

Diana's qualifications of Palauans as 'typical', 'regular', 'more openminded', and her comments regarding herself as 'new' or 'different' point towards the varied constructions of self as a consequence of transnational mobility. Regarding her proficiency in Palauan, she lamented not knowing some of the Palauan words that those residing in honto ${ }^{6}$ (Babeldaob, big island in Palau) used so casually. And to add to this, 'even my accent is kind of off a little bit'.

She perceived life in Palau as not changing at the same rate as the world outside and believed that studying abroad offered her an opportunity to exercise agency and keep pace with global trends. She stated: 'Well ... if you'd ask me, I'd say that going out and being educated is kind of my way of controlling things, you know'. Yet, she claimed she wanted to eventually disentangle herself from the trappings of all 'American things' and 'live a Palauan life' in honto where she could attend to her taro patch. ${ }^{7}$ As a child she had been very close to her now deceased maternal grandmother who had lived in honto and whom Diana would accompany to the taro patch. She reminisced that during those days there were no showers, or electricity or refrigerator, but she loved that life and wanted

6 'Honto' is a Japanese word appropriated by Palauans to refer to the big island of Babeldaob in Palau. Honto may be used in contrast to the commercial district of Koror to connote a more rural or traditionally Palauan lifestyle free of modern conveniences, such as electricity.

7 Tending the taro patch (mesei) is a cultural practice of Palauan women. The quality of taro (kukau or brak) may signify a woman's worth in the social system, in which women are expected to contribute starchy foods (ongraol) to complement the meat or fish (odoim) provided by men. Nowadays, some mechas (elderly women) continue to take pride in tending their taro patch, while many others hire foreign labour to grow their taro. 
to return to that idyllic past. She seemed to have a romanticised and static image of the 'old-fashioned' Palauan way of life from which she and her present reality were far removed.

Strikingly, like Dilumang, Diana also had strong postcolonial research interests with an emphasis on culturally relevant pedagogy. Intellectually, she was most keen to investigate Palauan efforts towards cultural revitalisation and passionately advocated that Palauans ought to take pride in their genealogy and history and their ties to the land. However, ironically, while studying abroad had equipped her with the theoretical and linguistic vocabulary to express her views, and further politicised her in the process, it had also created a cultural and linguistic lag between Diana and those she perceived to be 'true Palauan'. Her experience in Palau every time she returned from Hawai' $i$ betrayed her ambivalence and discomfort with readjustment to life in Palau. It seemed to me that transnational mobility had left her in some sort of limbo. She articulated her liminal predicament quite clearly:

Diana: It's a struggle. It's a struggle. I mean it's good to know you have two homes but having to constantly like transition, or, um, you know, adjust yourself to both environments and expectations that come from it. I mean especially coming to Palau. You know you have to reposition yourself back into the culture ... after living in Hawai i for a long time when you come back here you really have to change how you act. It's different. It's really different.

For Diana, life in Hawai'i afforded her the opportunity to improvise and reconstruct her sense of self. However, her return to Palau required her to subsume her improvisational transformations to the culturalist principles prevalent in Palau; in her words, she had to 'reposition' herself 'back into the culture', which had proven to be challenging. Therefore, the continuous shifting of cultural paradigms was a source of considerable stress for her.

\section{Theorising the agentive self: A comparative analysis}

Constructing the self is an ongoing process that is shaped by personal choices and actions and through relational interactions in the inhabited sociocultural and global environments. It may be as much a personally 
meaningful imaginative craft as it may be a product of societal norms and expectations and foreign influences. For Palauan youth, travel abroad may hypothetically offer an escape from cultural constraints and provide youth with more permissive spaces that allow for greater agency, improvisation and the refashioning of self, as aligned with the constructivist stance. However, upon return to Palau, youth may be expected to relinquish their newfound agency and slip into previously inhabited positional identities once again. They may experience customary obligations as burdensome and the constant subjugation of self under the dictates of Palauan society frustrating.

While this may indeed be the case for some, the conflation of life at home with the culturalist principle and lack of agency, and that of mobility with the constructivist position and manifested agency, may be far too simplistic and misleading. Individuals may choose to operate within a culturalist paradigm even when away from home, just as they may challenge imposed social roles and improvise on established norms when living in Palau. At times, the adoption of the culturalist perspective, for instance, in a global setting such as a foreign, multicultural university, may reflect agency, whereas improvisation may become a conditional necessity, rather than an act of deliberate intent.

Moreover, the culturalist and constructivist positions are not mutually exclusive and may overlap, coexist, bear different weight and be assigned alternative meanings in distinct phases and situations in a person's life. An individual may improvise to some degree while largely embracing a culturalist paradigm or vice versa. Choosing and balancing these paradigms may itself be a marker of agency, and one's choices may change with the passage of time, enabling fluid and 'continuous self-fashioning', as explained by Holland et al. Instances of cognitive dissonance- such as when a person may intellectually align herself with a particular paradigm but experientially prefer another in her daily life-as observed in the cases of Diana and Dilumang are especially revealing. In such cases, the coexistence of culturalist and constructivist paradigms may be fraught with tensions and ambivalence.

The narratives of both Diana and Dilumang demonstrate that their postcolonial leanings and intellectual allegiance to their homeland may not align smoothly with the experiential outcome upon return. Both experienced an unsettling cognitive dissonance between their imagined homeland and the reality of life in Palau. Their perception of a noticeable 
cultural and linguistic disconnect displays their self-reflexivity and keen awareness of the differences in the cultural worlds they inhabited. They believed that their academic achievements, or improvisational accomplishments, had empowered them to face Palauan society, bolstered their sense of self and encouraged them to reengage with their community, intellectually and more personally. However, both longed for unconditional acceptance from Palauans at home.

Dilumang wanted to accept the culturalist paradigm by re-establishing herself in the Palauan community and raising her children in her homeland. Returning to Palau was a definite marker of her agency for her because she did so on her own terms, against the advice and resistance she received from some of her relatives. But the culturalist principles that were imposed on her did not allow for an easy reconciliation with her constructivist scholarly self. Her academic accomplishments were belittled and despite being a single parent, she felt infantilised by community members. Her example provides an interesting contrast to the common refrain of customary obligations being burdensome for locals. While many Palauans, young and old, would rather extricate themselves from the trappings of siukang, Dilumang was keen to participate in such customs to consolidate her position as a productive member of Palauan society.

On the other hand, Hannah was able to successfully inhabit the culturally accepted position of a caring granddaughter. Her agency was reflected in the timing of her choice since she returned to Palau on her own accord and not when her grandmother wanted her to stay behind. Her example illustrates that travel abroad and improvisation need not be the only indicators of a person's ability to act even in highly structured social systems; a wilful decision to adopt the cultural paradigm may very well reflect individual agency.

Displays of agency by young returnees may not be restricted to selfconstruction. Palauan youth may effectively serve as agents of social change, who may be uniquely positioned to 'remake the world' they encounter in their homeland (Inden 1990: 23 quoted in Holland et al. 1998: 42). They may introduce fresh ideas about human rights, gender and sexuality, present alternative career paths and lifestyles, and broaden and redefine the imaginative boundaries of younger generations. 


\section{References}

Agarwal, R 2013, 'Asserting identity: youth culture, education and nationalism in contemporary Palau', Unpublished thesis, Brandeis University, Massachusetts.

Asang, I 2000, 'Remaking footprints: Palauan migrants in Hawai'i', The Contemporary Pacific, vol. 12, pp. 371-384. doi.org/10.1353/ cp. 2000.0040

Barnett, HG 1949, Palauan society: a study of contemporary native life in the Palau Islands, University of Oregon Publications, Eugene.

Conway, D, Potter, RB \& Phillips, J 2005, 'The experience of return: Caribbean migrants', in RB Potter, D Conway \& J Phillips (eds), The experience of return migration: Caribbean perspectives, Ashgate, Farnham, pp. 1-25.

Dolby, N \& Rizvi, F (eds) 2008, Youth moves: identities and education in global perspective, Routledge, New York \& London.

Gale, R 1979, The Americanization of Micronesia: a study of the consolidation of U.S. rule in the Pacific, University Press of America, Washington DC.

Gmelch, G 1980, 'Return Migration', Annual Review of Anthropology, vol. 9, pp. 135-159. doi.org/10.1146/annurev.an.09.100180.001031

Goffman, E 1956, The presentation of self in everyday life, University of Edinburgh, Social Sciences Research Centre, Edinburgh.

Heine, C 1974, Micronesia at the crossroads: a reappraisal of the Micronesian political dilemma, University of Hawai'i Press, Honolulu.

Hezel, FX 2001, The new shape of old island cultures: a half century of social change in Micronesia, University of Hawai'i Press, Honolulu.

Holland, D, Lachiocotte Jr, W, Skinner, D \& Cain, C 1998, Identity and agency in cultural worlds, Harvard University Press, Cambridge, Massachusetts and London, England.

Hughes, D \& Lingenfelter, SG (eds) 1974, Political development in Micronesia, Ohio State University Press, Columbus. 
Keate, G 2002 [1788], An account of the Pelew Islands, KL Nero and N Thomas (eds), Leicester University Press, London \& New York.

Kiste, R 1993, 'New political statuses in American Micronesia', in V Lockwood, T Harding \& B Wallace (eds), Contemporary Pacific societies: Studies in development and change, Pearson.

Koning, J 2005, 'The impossible return? The post-migration narratives of young women in rural Java', Asian Journal of Social Science, vol. 33, no. 2, pp. 165-185. doi.org/10.1163/1568531054930839

Lee-Cunin, M 2005, 'My motherland, or my mother's land? Return migration and the experience of young British-Trinidadians', in RB Potter, D Conway \& J Phillips (eds), The experience of return migration: Caribbean perspectives, Ashgate, Farnham, pp. 109-133.

Leibowitz, AH 1996, Embattled island: Palau's struggle for independence, Praeger Publishers, Westport, Connecticut and London.

McHenry, DF 1975, Micronesia, trust betrayed: altruism vs. self interest in American foreign policy, Carnegie Endowment for International Peace, New York and Washington.

Nero, KL \& Rehuher, FK 1993, 'Pursuing the dream: historical perspectives on Micronesian movement patterns', in G McCall \& J Connell (eds), A world perspective on Pacific Islander migration: Australia, New Zealand and the USA, Pacific Studies Monograph no. 6, Centre for South Pacific Studies, The University of New South Wales, Australia, pp. 239-255.

Nevin, D 1977, The American touch in Micronesia, WW Norton \& Company, New York.

Parmentier, RJ 1987, The sacred remains: myth, history, and polity in Belau, University of Chicago Press, Chicago.

Peacock, DJ 1987, Lee Boo of Belau: a prince in London, University of Hawai'i Press, Honolulu.

Pérez, GM 2005, 'A gendered tale of Puerto Rican return: place, nation and Identity', in RB Potter, D Conway \& J Phillips (eds), The experience of return migration: Caribbean perspectives, Ashgate, Farnham, pp. 183205. 
Potter, RB \& Conway, D 2005, 'Experiencing return: societal contributions, adaptations and frustrations', in RB Potter, D Conway \& J Phillips (eds), The experience of return migration: Caribbean perspectives, Ashgate, Farnham, pp. 283-287.

Smith, DR 1983, Palauan social structure, Rutgers University Press, New Brunswick.

Spivak, G 1988, Can the subaltern speak? Macmillan, Basingstoke.

Spivak, GC 1994, 'Can the subaltern speak?' in P Williams \& L Chrisman (eds), Colonial discourse and post-colonial theory: a reader, Columbia University Press, New York, pp. 66-111.

US Department of State, viewed 25 October 2015, www.state.gov/r/pa/ ei/bgn/1840.htm

Vidich, A 1949, Political factionalism in Palau: its rise and development, Coordinated Investigations in Micronesian Anthropology, Report no. 23, Pacific Science Board, Washington.

Wulff, H 1995, 'Introducing youth culture in its own right: the state of the art and new possibilities', in V Amit-Talai \& H Wulff (eds), Youth cultures: a cross-cultural perspective, Routledge, London \& New York, pp. 1-18. 
This text is taken from Mobilities of Return: Pacific Perspectives, edited by John Taylor and Helen Lee, published 2017 by ANU Press, The Australian National University, Canberra, Australia.

dx.doi.org/10.22459/MR.12.2017.05 